\title{
Effects of local isolates of Beauveria bassiana (Balsamo) Vuillemin on the two- spotted spider mite, Tetranychus urticae (Koch) (Acari: Tetranychidae)
}

\author{
Cenk Yucel(1)
}

\begin{abstract}
Background: The two-spotted spider mite, Tetranychus urticae (Koch) (Acari: Tetranychidae), is a widely distributed plant-feeding pest that causes significant yield losses in a wide range of crops. Newly developed or improved environmentally friendly biocontrol agents serve as an alternative to traditional pest control tools. Experiment of the effects of 2 local fungal isolates of Beauveria bassiana (BGF14 and BCA32) was carried out against T. urticae under laboratory conditions.

Results: Both tested isolates had lethal effect in a short time after application, and this effect increased as time progressed. BGF14 and BCA32 isolates caused T. urticae mortality rates ranging from 25.88 to 61.92 and 32.36 to $62.03 \%$ when applied at the concentrations between $1 \times 10^{5}$ and $1 \times 10^{8}$ conidia/ml, respectively. According to the Probit analysis performed on the effect of fungi on T. urticae adults, the $L C_{50}$ values of BGF14 and BCA32 isolates on the 7 th day after inoculation were $2.6 \times 10^{6}$ and $6.3 \times 10^{4}$ conidia/ml, respectively, and the $\mathrm{LT}_{50}$ values for both fungi applied at a concentration of $10^{8}$ conidia/ml were 2.14 and 2.23 days, respectively.

Conclusions: The 2 isolates of B. bassiana (BGF14 and BCA32) had the potentials to suppress T. urticae population and can be recommended as promising biocontrol agent candidates for control of T. urticae.
\end{abstract}

Keywords: Tetranychus urticae, Beauveria bassiana, Local isolates, Biological control

\section{Background}

The two-spotted spider mite [Tetranychus urticae Koch (Acari: Tetranychidae)] is an economic mite species that infects more than 900 different plant hosts and causes significant damage to at least 150 of them (Mondel and Ara 2006). T. urticae causes severe damage to crops in greenhouses and vegetable and fruit gardens in Turkey and all around the world (Van Den Boom et al. 2003). Accordingly, different types of synthetic acaricides are used to prevent the damage caused by the mite and to prevent its spread to other fields (Kumral et al. 2010). Insect resistance to pesticide is a growing problem

Correspondence: cenkyucel@gmail.com

Plant Protection Central Research Institute, 06172 Yenimahalle, Ankara, Turkey worldwide. Thus, the adoption of alternative control methods can minimize such problems. Nowadays, biocontrol agents such as entomopathogenic fungi (EPF) are widely used in integrated pest control (Faria and Wraight 2001). Beauveria bassiana (Hypocreales: Cordycipitaceae), for example, has been identified as a pathogen of several mites' species (Faria and Wraight 2007) that is highly effective in reducing mites' populations. Chandler et al. (2005) conducted greenhouse trials using a commercial isolate of B. bassiana (Naturalis L.) against T. urticae and reported that this fungus greatly reduced the number of mobile mites compared to the untreated control. Numerous studies have also been conducted to determine the possible use of EPF in biological control of mites (Gatarayiha et al. 2011). 
Among the alternative complementary and supplementary methods to overcome the issue of resistance to chemical control, use of entomopathogenic fungi (EPF) has occupied an important place in biological control methods. Currently, use of $B$. bassiana in bio-preparations has become common in the world.

In this study, the pathogenicity of two local isolates of B. bassiana, isolated from Turkey's nature, was investigated against $T$. urticae adults under laboratory conditions.

\section{Methods}

\section{Mite culture}

Tetranychus urticae was reared on bean plants (Phaseolus vulgaris L.) grown in pots placed in a climate room with temperature of $24 \pm 1{ }^{\circ} \mathrm{C}$, relative humidity of $65 \pm 1$, and $14: 10$ photoperiod.

\section{Identification of fungus}

\section{Morphological identification of fungus}

Two isolates of EPF were obtained from the body of insect cadaver. The fungus was morphologically identified under a light microscope according to its conidial features in accordance with the literatures (Samson et al. 1988; Goettel and Inglis 1997; Humber 1998). The isolates were developed on PDA (potato dextrose agar) by incubating them at $23 \pm 1{ }^{\circ} \mathrm{C}$, including $12 \mathrm{~h}$ light (near ultraviolet light) $12 \mathrm{~h}$ dark for 10-12 days. The fungus colonies showed very quick growth by covering Petri dishes in 10 days. The colony color was first white, and then changed close to creamy white. The colonies had a white velvety appearance. Both isolates had an aerial miselium, intense wool-like miselium structure. It was observed that the fungus produced too many conidia. The conidia measured $2-2.5-\mu \mathrm{m}$ diameter. The conidia occured in 3 days in Petri dishes (Fig. 1).

\section{Fungal pathogens and preparation of the conidial suspensions}

In this study, $B$. bassiana isolates were obtained from the fungal collection of the Plant Protection Research Center and Institute. The 2 isolates were obtained from a body of insect cadaver. BGF14 isolate was isolated from Gonioctena fornicata (Brüggmen) (Coleoptera: Chrysomelidae), while BCA32 was from Cicadatra adanai Kartal (Hemiptera: Cicadidae). Fungus cultures were maintained on Sabouraud dextrose agar (SDA) at $24 \pm 1{ }^{\circ} \mathrm{C}$ for 21 days. Conidial suspensions were filtered through 3 layers of sterile cheesecloth to remove particles. The number of conidia per milliliter was counted using a hemocytometer. At the end of this period, the conidia were collected in sterile distilled water containing $0.02 \%$ Tween 80 , and the conidial concentration of the stock culture was adjusted to a density of $1 \times 10^{8}$ conidia $/ \mathrm{ml}$.

\section{Molecular identification of fungus}

In the molecular studies, DNA extraction was carried out using 10-12-day-old culture with Qiagen Blood and Tissue Kit. PCR protocol was undertaken using ITS1 and ITS4 gene region. The positive isolates were sent to the sequencing facilities. The sequence results were opened software program called BIOEDIT, and nucleotide sequences were blasted in the NCBI website. As a consequence of blasted sequences that were showed $(100 \%)$ homology with the other sequences; B. bassiana. The deposited accession numbers on the NCBI website of the 2 B. bassiana isolates are MW295632 and MW295633, respectively.

\section{Bioactivity of entomopathogenic fungi}

First, bean leaves were cut and placed on moist filter papers in a $3-\mathrm{cm}$ Petri dish; then, $1 \mathrm{ml}$ suspension of each of BGF14 and BCA32 with $1 \times 10^{5}, 1 \times 10^{6}, 1 \times 10^{7}$, and $1 \times 10^{8}$ conidial concentrations was sprayed on the leaves, using a spray tower device (Burkard Manufacturing Co. Ltd., Rickmansworth, Herts, UK) (Kumral et al. 2010). Petroleum jelly was applied to edges of the leaves that were left to air dry for $30 \mathrm{~min}$. Afterwards, $T$. urticae females (1-2 days old females were tested) were placed on the leaves using a paint brush for each dose. The control group was sprayed with
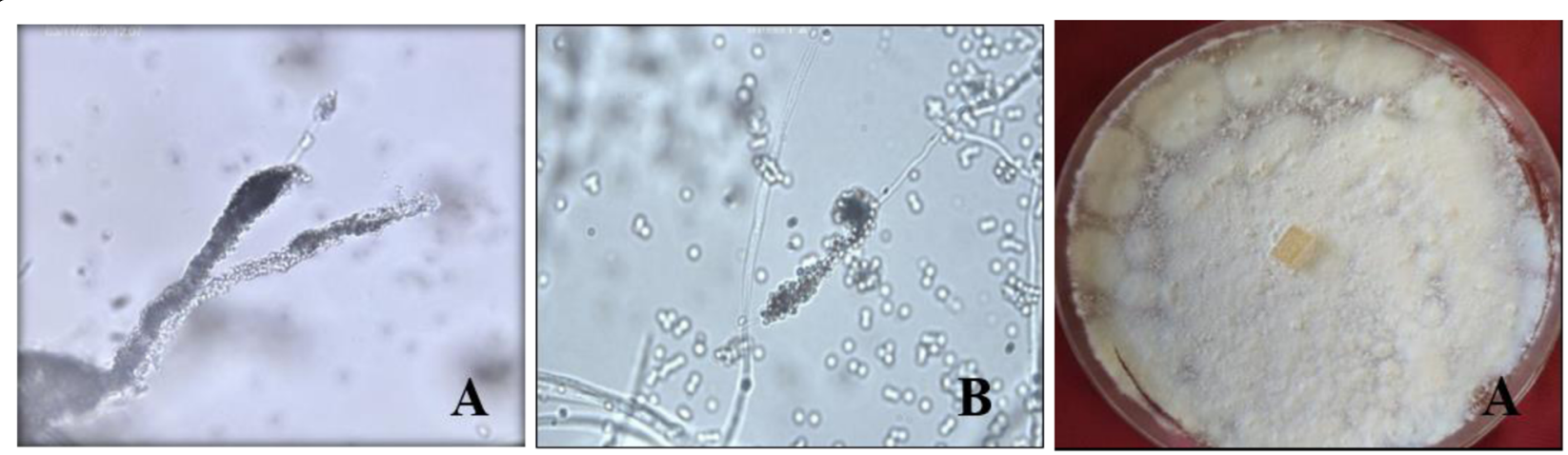

Fig. 1 Conidia of BGF14 (a) and BCA32 (b) isolates of Beauveria bassiana $(\times 100 \mu \mathrm{m})$ and fungal growth in PDA media 
water containing $0.02 \%$ Tween 80 on leaves, using a spray tower device. The experiments were carried out at room temperature of $24 \pm 1{ }^{\circ} \mathrm{C}, \mathrm{RH}$ of $65 \pm 1 \%$, and 14:10 photoperiod. The experiments were monitored after 3, 5, and 7 days post-application, and the ratios of dead and alive mites were recorded using a stereomicroscope. Each dose had 4 replicates (60 tested individuals), and the experiments were repeated 3 times for BGF14 and twice for BCA32.

\section{Data analysis}

The data obtained in the study was converted to measurements' percentage, transformed using arc-sin transformation, and then analyzed with analysis of variance (ANOVA). Percentage mortality was corrected by Abbott (1925). Comparisons between the percentage mortality were made using Duncan's multiple comparison test. The $\mathrm{LC}_{50}$ and $\mathrm{LT}_{50}$ values were calculated according to Finney (1971) in POLO-PC package program. All statistical analyses were done in SPSS 23.0 package program (IBM Corp, 2013).

\section{Results}

The first record of T. urticae mortality was recorded 3 days after treatment. On the 3rd day, concentrations of BGF14 and BCA32 isolates between $10^{5}$ and $10^{8}$ conidia/ $\mathrm{ml}$ exhibited mortality rate ranging between 25.88 and $61.92 \%$ and between 32.36 and $62.03 \%$, respectively. On the same day, mortality rates in the control treatments were $8.32 \%$ (for BGF14) and $11.67 \%$ (for BCA32). On the 7 th day, the efficacy of the fungal isolates increased significantly to $48.08-82.50 \%$ mortality rates recorded for BGF14 and $67.92-90.95 \%$ for BCA32 between the tested concentrations, respectively. As for the control group, it was $23.38 \%$ (BGF14) and 28.81\% (BCA32) (Fig. 2).

After the application of B. bassiana BGF14 on the adults of T. urticae, it was observed that the fungus

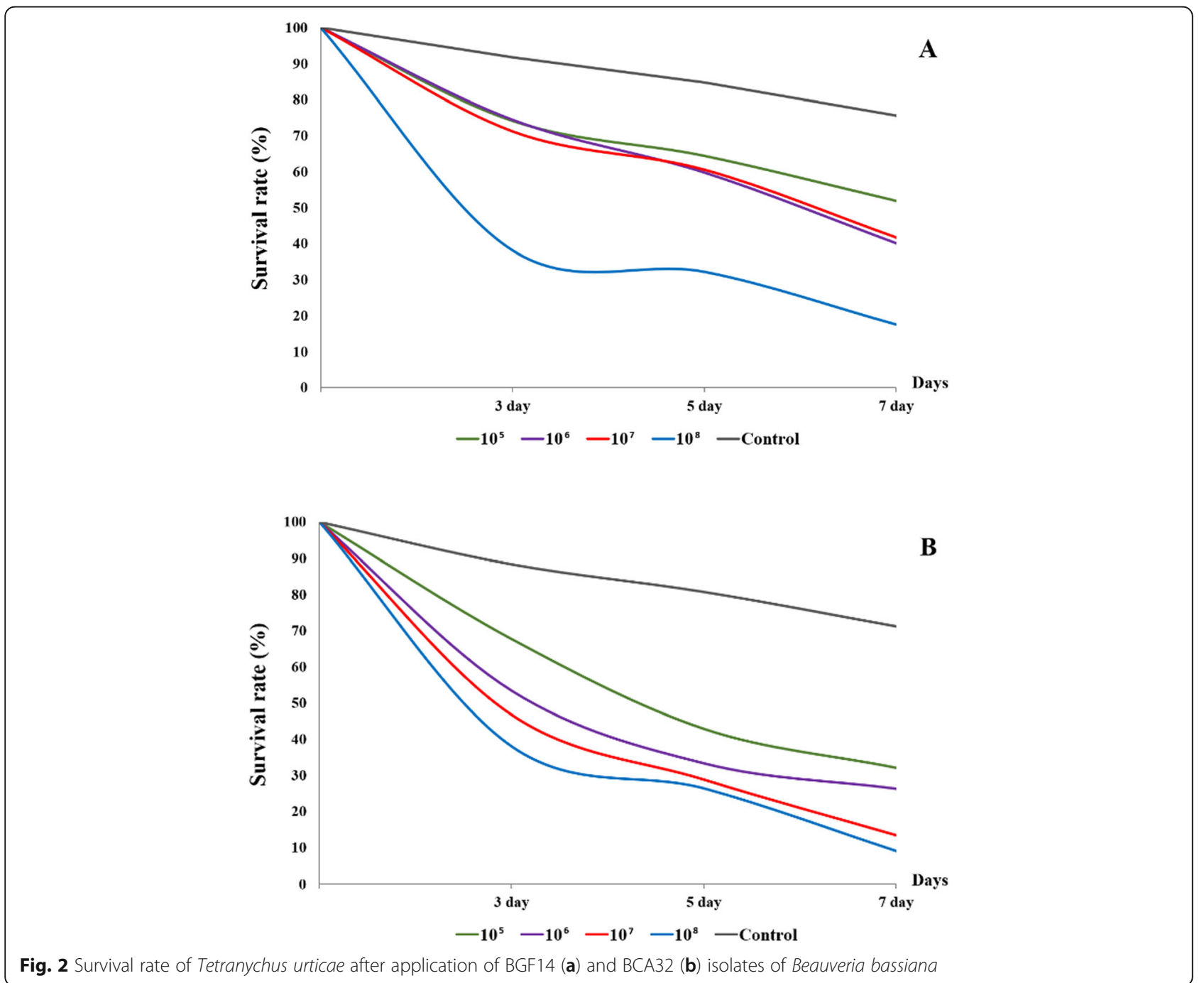


continued to develop, and its effect increased in the following days (Fig. 3). The pathogenicity of the $\left(10^{8}\right.$ conidia $/ \mathrm{ml}$ ) application increased from $50 \%$ on the 3rd day to the highest of $76.98 \%$ as incubation progresses whereas the effect was less than $50 \%$ for the other tested concentrations, including $10^{6}$ and $10^{7}$ conidia $/ \mathrm{ml}$.

In the case of the isolate $\mathrm{BCA} 32$, fungal growth continued increasingly only after the 5 th day. On the 3rd day, the fungus at $10^{7}$ and $10^{8}$ conidia/ml concentrations caused more than $50 \%$ mortality than the untreated control group. The highest effect was exhibited by $10^{8}$ conidia/ml concentration on the 7 th day with $87.27 \%$ mortality, followed by $10^{7}$ conidia $/ \mathrm{ml}$ concentration $(81.09 \%)$, with non-statistical difference between the mortality by the two concentrations (Table 1 ).

Probit analysis was used to determine the $\mathrm{LC}_{50}$ and $\mathrm{LT}_{50}$ values of fungi in this study. The $\mathrm{LC}_{50}$ after 3 days of application with the B. bassiana isolate BGF14 to $T$. urticae populations was $1.1 \times 10^{7}$ conidia/ml, whereas it was low after 7 days of application with $2.6 \times 10^{6}$ conidia/ $\mathrm{ml}$. Concentration values of $B$. bassiana BCA32 were lower than BGF14. The $\mathrm{LC}_{50}$ value of the BCA32 isolate was $1.3 \times 10^{6}$ conidia/ml on the 3 rd day and $6.3 \times 10^{4}$ conidia/ml on the 7 th day (Table 2).

According to the data analysis, $\mathrm{LT}_{50}$ value of $\mathrm{B}$. bassiana isolate BGF14 for the concentration of $10^{8}$ conidia/ $\mathrm{ml}$ was determined after 2.14 days, whereas similar effects were determined for the other treatments after 5.84-7.73 days. As for the other B. bassiana isolate,
BCA32 had a short $\mathrm{LT}_{50}$ value of $2.23-4.27$ days. The $\mathrm{LT}_{50}$ value was 2.23 days at the concentration of $1 \times 10^{8}$ conidia/ml (Table 3).

\section{Discussion}

The T. urticae is a global pest in greenhouse and field crops (Wekesa et al. 2011). In this study, the efficacy of 2 different $B$. bassiana isolates was evaluated against $T$. urticae under laboratory conditions.

Conidial concentrations and fungal isolates differed in adult viability: the greatest concentration the highest mortality of adults. According to Shi and Feng (2004), the mortality rate differed between the fungal isolates and conidial concentrations. In parallel with the results obtained in this study, $73.1 \%$ of $T$. urticae mites died within 10 days of applying $B$. bassiana (Shi and Feng 2009). Also, it has been reported that the efficacy of 5 different isolates of $B$. bassiana showed lethal effects ranging between 68.49 and $83.78 \%$ on the first day of application and $100 \%$ on the 4th day (Draganova and Simova 2010). Geroh et al. (2014) stated that on the 7th day, $0.3 \times 10^{8}$ conidia/ml concentration of $B$. bassiana was effective against $T$. urticae causing $63.31 \%$ mite mortality. In another study, Örtücü and Algur (2017) found that the pathogenicity effects of the 2 different isolates of B. bassiana on T. urticae was $24-60 \%$ on the 3rd day, $62.7-88 \%$ on the 5 th day, and $90.7-100 \%$ on the 7th day. Shin et al. (2017) reported that 3 isolates of B. bassiana applied at the concentration of $10^{8}$ conidia/

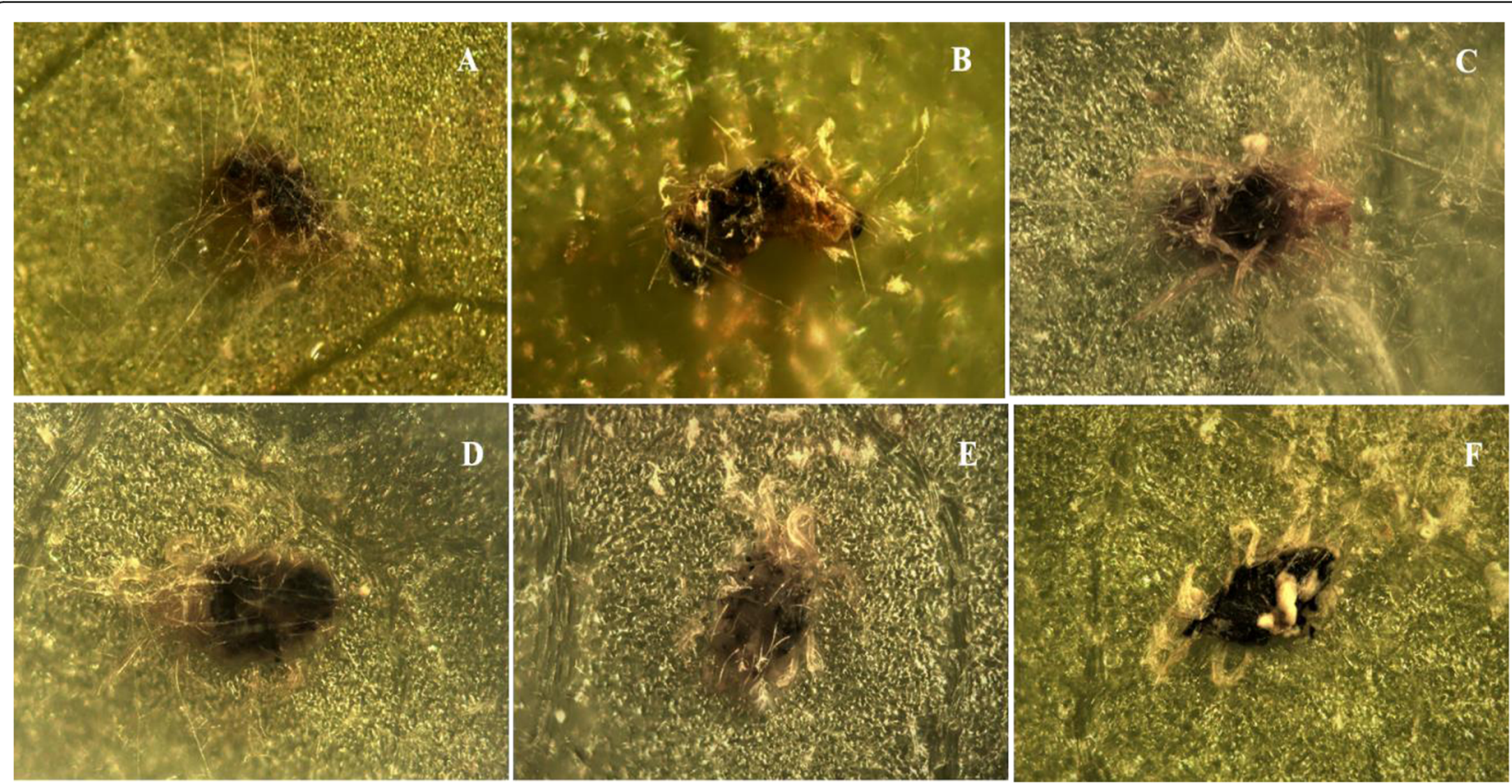

Fig. 3 Tetranychus urticae individuals infected with BGF14 isolate of Beauveria bassiana after 3 days (a), 5 days (b), and 7 days (c) and BCA32 isolate after 3 days (d), 5 days (e), and 7 days (f) 
Table 1 Corrected mortality of BGF14 and BCA32 isolates of Beauveria bassiana against Tetranychus urticae adults

\begin{tabular}{|c|c|c|c|c|c|c|c|c|c|c|c|c|c|c|c|}
\hline & \multirow[t]{3}{*}{ Days } & \multirow{3}{*}{$\begin{array}{l}\text { Control } \\
\text { mortality } \pm \text { SE }\end{array}$} & \multicolumn{13}{|c|}{ Corrected efficacy \pm SE } \\
\hline & & & \multicolumn{13}{|c|}{ Conidial suspensions at concentration (conidia/ml) } \\
\hline & & & $1 \times 10^{5}$ & & & $1 \times 10^{6}$ & & & $1 \times 10^{7}$ & & & $1 \times 10^{8}$ & & & $F$ ratio \\
\hline \multirow[t]{4}{*}{ BGF14 } & 3 & $8.32 \pm 1.64$ & $19.16 \pm 2.03$ & $B^{*}$ & $b^{* *}$ & $18.89 \pm 2.10$ & C & $b$ & $22.30 \pm 3.75$ & B & $b$ & $58.38 \pm 3.08$ & B & a & 45.828 \\
\hline & 5 & $15.17 \pm 2.01$ & $24.01 \pm 2.24$ & B & $b$ & $29.39 \pm 4.10$ & B & $b$ & $28.63 \pm 3.49$ & B & $b$ & $62.05 \pm 3.60$ & B & a & 26.181 \\
\hline & 7 & $24.38 \pm 3.20$ & $31.44 \pm 2.76$ & A & c & $47.10 \pm 2.94$ & A & b & $44.95 \pm 3.62$ & A & b & $76.98 \pm 3.32$ & A & a & 36.520 \\
\hline & & $F$ ratio & 6.854 & & & 20.433 & & & 10.413 & & & 8.699 & & & $P \leq 0.05$ \\
\hline \multirow[t]{4}{*}{ BCA32 } & 3 & $11.67 \pm 1.43$ & $24.44 \pm 4.77$ & $B^{*}$ & $c^{* *}$ & $40.72 \pm 3.95$ & B & $b$ & $48.21 \pm 4.99$ & $C$ & $a b$ & $57.94 \pm 3.66$ & $B$ & a & 10.446 \\
\hline & 5 & $19.28 \pm 2.20$ & $46.87 \pm 3.69$ & $A$ & $b$ & $58.68 \pm 3.75$ & A & a & $64.24 \pm 2.80$ & $B$ & a & $67.37 \pm 3.44$ & $B$ & a & 6.890 \\
\hline & 7 & $28.81 \pm 0.98$ & $54.89 \pm 3.27$ & A & $b$ & $63.06 \pm 1.95$ & A & b & $81.09 \pm 4.10$ & A & a & $87.27 \pm 2.76$ & A & a & 23.556 \\
\hline & & $F$ ratio & 15.892 & & & 12.560 & & & 16.355 & & & 20.515 & & & $P \leq 0.05$ \\
\hline
\end{tabular}

*Means within column bearing the same letter are not significantly different (Duncan's test, $p>0.05$ )

**Means within lines bearing the same letter are not significantly different (Duncan's test, $p>0.05$ )

ml caused 55-82\% T. urticae mortality, whereas the different isolates used in a study by Yanar et al. (2018) had $32.5-72.5 \%$ effect on $T$. urticae when applied at $5 \times 10^{6}$ effect rate. Wu et al. (2020) also found that a $0.7 \times 10^{5}$ conidia $/ \mathrm{ml}$ concentration of $B$. bassiana was highly effective with a mortality rate of $63.2-72.1 \%$ in $T$. urticae adults. Enzymes produced by each isolate may be correlated to the difference in virulence between the different fungal isolates of T. urticae.

This study revealed that the 2 native $B$. bassiana isolates (BGF14 and BCA32) and their metabolites had toxic effects on $T$. urticae adults. The $\mathrm{LC}_{50}$ value was high between treatments, and development of mycosis was observed after 3 days of application. These agree with the previous studies carried out by Geroh et al. (2015) who determined that $1 \times 10^{5}-1 \times 10^{8}$ conidia $/ \mathrm{ml}$ concentrations of $B$. bassiana applied to $T$. urticae adults showed $42-64 \%$ effects against the mite when the $\mathrm{LC}_{50}$ was $0.3 \times 10^{8}$ conidia/ml. Moreover, Elhakim et al. (2020) stated that B. bassiana caused 15 to $70 \%$ mortality against $T$. urticae, and its $\mathrm{LC}_{50}$ and $\mathrm{LC}_{90}$ values estimated $3.3 \times 10^{6}$ and $7.8 \times 10^{9}$ conidia/ml, respectively. It was also determined that $B$. bassiana caused 56.482.6\% mortality against Tetranychus evansi, and the $\mathrm{LC}_{50}$ value was $1.1 \times 10^{7}$ conidia/ml on the 7 th day (Wekesa et al. 2005). Chandler et al. (2005) stated that the $\mathrm{LC}_{25}$ value of $B$. bassiana was $8.65 \times 10^{7} 6$ days postinoculation into T. urticae adults. Irigaray et al. (2003) reported that the commercial isolate of $B$. bassiana (Naturalis L.) had a $\mathrm{LC}_{50}$ value of $1.9 \times 10^{3}$ conidia $/ \mathrm{ml}$ against $T$. urticae adults.

Furthermore, results of applying 2 different isolates of B. bassiana to Tetranychus cinnabarinus showed that the $\mathrm{LT}_{50}$ value was 3.6-5.8 days at the concentration of $1.5 \times 10^{3}$ conidia/ml (Shi et al. 2008). In another study, under greenhouse conditions, the $\mathrm{LT}_{50}$ value for a $1 \times 10^{8}$ conidia/ml concentration of $B$. bassiana against Tetranychus kanzawai was found to be 3.98-5.48 days, and the $\mathrm{LT}_{90}$ value was 9.58-15.78 days (Sanjaya et al. 2016). The $\mathrm{LT}_{50}$ value of 3 different isolates of $B$. bassiana after applied to $T$. urticae was 3.16-3.72 days (Örtücü and İskender 2017). These results are consistent with a previous study that the local strains used in this study had a high pathogenic effect against $T$. urticae. Evaluating the compatibility of EPF is a critical issue for the successful implementation of IPM programs to control pest mite species (Vergel et al. 2011).

\section{Conclusion}

Pathogenic potentials of 2 local isolates of $B$. bassiana against $T$. urticae were studied. In a relatively short period, BCA32 was highly efficacious and exhibited

Table 2 Median lethal concentration ( $\left(\mathrm{C}_{50}\right.$ ) of Beauveria bassiana (BGF14 and BCA32 isolates) against Tetranychus urticae adults

\begin{tabular}{lllllll}
\hline EPF $^{\mathbf{a}}$ & Days & $\mathbf{X}^{\mathbf{2}}$ & df & Slope \pm SE & LC $_{50}$ (conidia/ml) & 95\% Confidence intervals \\
\hline BGF14 & 3 & 28.25 & 45 & $0.359 \pm 0.071$ & $1.1 \times 10^{7}$ & $0.4 \times 10^{7}-9.9 \times 10^{7}$ \\
& 5 & 25.65 & 45 & $0.388 \pm 0.096$ & $0.9 \times 10^{7}$ & $0.3 \times 10^{7}-1.3 \times 10^{7}$ \\
& 7 & 20.87 & 45 & $0.353 \pm 0.072$ & $2.6 \times 10^{6}$ & $0.8 \times 10^{6}-7.1 \times 10^{6}$ \\
BCA32 & 3 & 17.02 & 29 & $0.270 \pm 0.071$ & $1.3 \times 10^{6}$ & $0.4 \times 10^{6}-1.2 \times 10^{7}$ \\
& 5 & 12.05 & 29 & $0.219 \pm 0.077$ & $2.7 \times 10^{5}$ & $0.6 \times 10^{4}-1.6 \times 10^{6}$ \\
& 7 & 8.95 & 29 & $0.355 \pm 0.086$ & $6.3 \times 10^{4}$ & $1.4 \times 10^{3}-3.0 \times 10^{5}$ \\
\hline
\end{tabular}


Table 3 Median lethal time ( $\left(T_{50}\right)$ values of BGF14 and BCA32 isolates of Beauveria bassiana against Tetranychus urticae adults

\begin{tabular}{lllllll}
\hline EPF $^{\mathbf{a}}$ & Fungal conidial conc./ml & $\mathbf{X}^{\mathbf{2}}$ & $\mathbf{d f}$ & Slope $\mathbf{S E}$ & $\mathbf{L T}_{\mathbf{5 0}}$ (days) & $\mathbf{9 5 \% \text { Confidence intervals }}$ \\
\hline BGF14 & $10^{5}$ & 6.48 & 33 & $1.602 \pm 0.466$ & 7.73 & $6.10-15.00$ \\
& $10^{6}$ & 12.93 & 33 & $2.389 \pm 0.482$ & 5.84 & $5.08-7.23$ \\
& $10^{7}$ & 16.35 & 33 & $2.002 \pm 0.457$ & 6.09 & $5.20-8.08$ \\
& $10^{8}$ & 15.11 & 33 & $1.648 \pm 0.495$ & 2.14 & $0.71-2.95$ \\
BCA32 & $10^{5}$ & 6.57 & 21 & $2.839 \pm 0.577$ & 4.27 & $3.62-4.90$ \\
& $10^{6}$ & 7.18 & 21 & $2.847 \pm 0.763$ & 3.29 & $2.41-3.77$ \\
& $10^{7}$ & 11.36 & 21 & $2.615 \pm 0.571$ & 3.01 & $2.13-3.58$ \\
& $10^{8}$ & 8.48 & 21 & $1.946 \pm 0.573$ & 2.23 & $0.84-3.00$ \\
\hline
\end{tabular}

Entomopathogenic fungi

mortality rate that exceeded $50 \%$ at low concentrations. BGF14 also caused mortality rate more than $50 \%$ in high concentrations, but it lasted a long period to exhibit this compared to BCA32. Further studies are needed to determine the effectiveness of these 2 local isolates against T. urticae under field conditions and in greenhouses.

\section{Abbreviations}

EPF: Entomopathogenic fungi; BGF14: Beauveria bassiana [isolated from Gonioctena fornicata (Brüggmen)]; BCA32: Beauveria bassiana (isolated from Cicadatra adanai Kartal); DNA: Deoxyribonucleic acid; PCR: Polymerase chain reaction; $\mathrm{LT}_{50}$ : Median lethal time; $\mathrm{LC}_{50}$ : Median lethal concentration; SDA: Sabouraud dextrose agar; PDA: Potato dextrose agar; NCBI: National Center for Biotechnology Information; ANOVA: Analysis of variance; \pm SE: Positive or negative standard error

\section{Acknowledgements}

I would like to thank Dr A Baris, S Tulek, T S Ertek, and the Plant Protection Central Research Institute, Ankara, Turkey, for the support provided throughout the research work.

\section{Author's contributions}

The author has developed and implemented this review article and written it. The author read and approved the final manuscript.

\section{Funding}

Financial support made by the Plant Protection Central Research Institute, Turkey, is gratefully acknowledged.

\section{Availability of data and materials}

The datasets used and/or analyzed during the current study are available from the corresponding author on reasonable request.

\section{Declarations}

Ethics approval and consent to participate

Not applicable.

\section{Consent for publication}

Not applicable.

\section{Competing interests}

The author declares that he has no competing interests.

Received: 10 December 2020 Accepted: 1 April 2021

Published online: 16 April 2021

\section{References}

Abbott WS (1925) A method for computing the effectiveness of insecticides. J Econ Entom 18(2):265-267. https://doi.org/10.1093/jee/18.2.265a

Chandler D, Davidson G, Jacobson RS (2005) Laboratory and glasshouse evaluation of entomopathogenic fungi against the two-spotted spider mite,
Tetranychus urticae (Acari: Tetranychidae), on tomato, Lycopersicon esculentum. Biocontrol Sci Technol 15(1):37-54. https://doi.org/10.1080/ 09583150410001720617

Draganova SA, Simova SA (2010) Susceptibility of Tetranychus urticae Koch. (Acari: Tetranychidae) to isolates of entomopathogenic fungus Beauveria bassiana. J Pestic Phytomed 25(1):51-57. https://doi.org/10.2298/PIF1001051D

Elhakim E, Mohamed O, Elazouni I (2020) Virulence and proteolytic activity of entomopathogenic fungi against the twospotted spider mite, Tetranychus urticae Koch (Acari: Tetranychidae). Egypt J Biol Pest Control 30(1):30. https:// doi.org/10.1186/s41938-020-00227-y

Faria MR, Wraight SP (2001) Biological control of Bemisia tabaci with fungi. Crop Prot 20(9):767-778. https://doi.org/10.1016/S0261-2194(01)00110-7

Faria MR, Wraight SP (2007) Mycoinsecticides and mycoacaricides: a comprehensive list with worldwide coverage and International classification of formulation types. Biol Control 43(3):237-256. https://doi.org/10.1016/j. biocontrol.2007.08.001

Finney DJ (1971) Probit analysis, 3rd edn. Cambridge University Press, Cambridge

Gatarayiha MC, Laing MD, Miller RM (2011) Field evaluation of Beauveria bassiana efficacy for the control of Tetranychus urticae Koch (Acari: Tetranychidae). J Appl Entomol 135(8):582-592. https://doi.org/10.1111/ j.1439-0418.2010.01569.x

Geroh M, Gulati R, Tehri K (2014) Beauveria bassiana (Balsamo) Vuillemin (strain ITCC-4668) as acaricide against Tetranychus urticae Koch (Acari: Tetranychidae). Indian J Agric Res 48(5):384-388. https://doi.org/10.5958/ 0976-058X.2014.01319.5

Geroh M, Gulati R, Tehri K (2015) Determination of lethal concentration and lethal time of entomopathogen Beauveria bassiana (Balsamo) Vuillemin against Tetranychus urticae Koch. Int J Agric Sci 7(5):523-528

Goettel MS, Inglis GD (1997) Fungi: hyphomycetes. In: Lacey LA (ed) Manual of techniques in insect pathology. Academic Press, San Diego, pp 213-249. https://doi.org/10.1016/B978-012432555-5/50013-0

Humber RA (1998) Entomopathogenic fungal identification. APS/ESA Joint Annual Meeting 8-12 November 1998 Las Vegas, NV.

IBM Corp. IBM SPSS Statistics for Windows, Version 23.0. Armonk: IBM Corp; 2013.

Irigaray FJS, Marco-Mancebon V, Perez-Moreno I (2003) The entomopathogenic fungus Beauveria bassiana and its compatibility with triflumuron: effect on the two-spotted spider mite, Tetranychus urticae. Biol Control 26(2):168-173. https://doi.org/10.1016/S1049-9644(02)00123-8

Kumral NA, Çobanoğlu S, Yalçın C (2010) Acaricidal, repellent and oviposition deterrent activities of Datura stramonium L. against adult Tetranychus urticae (Koch). J Pest Sci 83(2):173-180. https://doi.org/10.1007/s10340009-0284-7

Mondel M, Ara N (2006) Biology and fecundity of the two spotted spider mite, Tetranychus urticae Koch. (Acari: Tetranychidae) under laboratory conditions. J Life Earth Sci 1:43-47

Örtücü S, Algur ÖF (2017) A laboratory assessment of two local strains of the Beauveria bassiana (Bals.) Vuill. against the Tetranychus urticae (Acari: Tetranychidae) and their potential as a mycopesticide. Hindawi J Pathogens $\checkmark$ 7628175:7

Örtücü S, İskender NA (2017) Determination of control potentials and enzyme activities of Beauveria bassiana (Bals.) Vull. isolates against Tetranychus urticae Koch (Acari: Tetranychidae). Trak Univ J Nat Sci 18(1):33-38

Samson RA, Evans HC, Latge JP (1988) Atlas of entomopathogenic fungi. SpringerVerlag, New York. https://doi.org/10.1007/978-3-662-05890-9 
Sanjaya Y, Ocampo VR, Caoili BL (2016) Pathogenicity of three entomopathogenic fungi, Metarhizium anisopliae, Beauveria bassiana, and Paecilomyces lilacinus, to Tetranychus kanzawai infesting Papaya seedlings. Arthropods 5(3):109-113

Shi WB, Feng MG (2004) Lethal effect of Beauveria bassiana, Metarhizium anisopliae, and Paecilomyces fumosoroseus on the eggs of Tetranychus cinnabarinus (Acari: Tetranychidae) with a description of a mite egg bioassay system. Biol Control 30(2):165-173. https://doi.org/10.1016/j. biocontrol.2004.01.017

Shi WB, Feng MG (2009) Effect of fungal infection on reproductive potential and survival time of Tetranychus urticae (Acari: Tetranychidae). Exp Appl Acarol 48(3):229-237. https://doi.org/10.1007/s10493-009-9238-2

Shi WB, Zhang L, Feng MG (2008) Time concentration mortality responses of Carmine spider mite (Acari: Tetranychidae) females to three Hypocrealean fungi as biocontrol agents. Biol Control 46(3):495-501. https://doi.org/10.101 6/j.biocontrol.2008.04.006

Shin TY, Bae SM, Kim DJ, Yun HG, Woo SD (2017) Evaluation of virulence, tolerance to environmental factors and antimicrobial activities of entomopathogenic fungi against two-spotted spider mite, Tetranychus urticae. Mycoscience 58(3):204-212. https://doi.org/10.1016/j.myc.2017.02.002

Van Den Boom CEM, Van Beek TA, Dicke M (2003) Differences among plant species in acceptance by the spider mite Tetranychus urticae Koch. J Appl Entomol 127(3):177-183. https://doi.org/10.1046/j.1439-0418.2003.00726.x

Vergel SJN, Bustos RA, Rodríguez CD, Cantor RF (2011) Laboratory and greenhouse evaluation of the entomopathogenic fungi and garlic-pepper extract on the predatory mites, Phytoseiulus persimilis and Neoseiulus californicus and their effect on the spider mite Tetranychus urticae. Biol Control 57(2):143-149. https://doi.org/10.1016/j.biocontrol.2011.02.007

Wekesa VW, Maniania NK, Knapp M, Boga HI (2005) Pathogenicity of Beauveria bassiana and Metarhizium anisopliae to the tobacco spider mite Tetranychus evansi. Exp Appl Acarol 36(1):41-50. https://doi.org/10.1 007/s10493-005-0508-3

Wekesa WW, Vital S, Silva RA, Ortega EMM, Klingen I, Delalibera I (2011) The effect of host plants on Tetranychus evansi, Tetranychus urticae (Acari: Tetranychidae) and on their fungal pathogen Neozygites floridana (Entomophthorales: Neozygitaceae). J Invertebr Pathol 107(2):139-145. https://doi.org/10.1016/j.jip.2011.04.003

Wu S, Sarkar SC, Lv J, Xu X, Lei Z (2020) Poor infectivity of Beauveria bassiana to eggs and immatures causes the failure of suppression on Tetranychus urticae population. BioControl 65(1):81-90. https://doi.org/1 0.1007/s10526-019-09970-0

Yanar D, Yanar Y, Belgüzar S, Eser I, Ünalan KH (2018) Efficacy of entomopathogenic fungus Beauveria bassiana isolates against the twospotted spider mite, Tetranychus urticae Koch (Acari: Tetranychidae). Appl Ecol Environ Res 16(6):7903-7911. https://doi.org/10.15666/aeer/1606_ 79037911

\section{Publisher's Note}

Springer Nature remains neutral with regard to jurisdictional claims in published maps and institutional affiliations.

\section{Submit your manuscript to a SpringerOpen ${ }^{\circ}$ journal and benefit from:}

- Convenient online submission

- Rigorous peer review

- Open access: articles freely available online

- High visibility within the field

- Retaining the copyright to your article

Submit your next manuscript at $\boldsymbol{\nabla}$ springeropen.com 